\title{
Relational Persons and Relational Processes: \\ Developing the Notion of Relationality \\ for the Sociology of Personal Life
}

\section{Sasha Roseneil and Kaisa Ketokivi}

\section{Corresponding Author:}

Sasha Roseneil, Department of Psychosocial Studies, Birkbeck, University of London, London WCIE 7HX.

s.roseneil@bbk.ac.uk

\begin{abstract}
The concept of relationality has recently found widespread favour in British sociology, particularly in the emergent sub-field of the sociology of personal life, which is characterised by its attachment to the concept. However, this 'relational turn' is undertheorized and pays little attention to the substantial history of relational thinking across the human sciences. This paper argues that the notion of relationality in the sociology of personal life might be strengthened by an exploration of the conceptualization of the relational person and relational processes offered by three bodies of literature: the process oriented thinking of American pragmatism, specifically of Mead and Emirbayer; the figurational sociology of Elias; and psychoanalysis, particularly the object relations tradition, contemporary relational psychoanalysis and Ettinger's notion of transubjectivity. The paper attends particularly to the processes involved in the individuality, agentic reflexivity and affective dimensions of the relational person.
\end{abstract}

\section{Keywords:}

affect, agentic reflexivity, figurational sociology, individuality, individualization, intimacy, personal life, pragmatism, psychoanalysis, relationality, transubjectivity 
In recent years the concept of relationality, and the characterisation of practices and aspects of sociality as 'relational', have found widespread favour amongst British sociologists concerned with the study of intimacy, family and personal life. In this paper we argue that this 'relational turn' would benefit from further theorizing, as it appears to have taken place with little attention to the considerable history and contemporary scope of discussions about relationality across the human sciences. We seek to develop the sociological notion of relationality through a focus on the conceptualization of the relational person and relational processes. We draw on three bodies of work - American pragmatism, figurational sociology and psychoanalytic thought - which offer theorizations of relational selves and subjectivities and processual ontologies that might broaden and deepen sociological understandings of relationality. ${ }^{i}$

We begin by outlining the emergence of the sociology of personal life as a field of inquiry characterized by what might be called a 'relational turn'. We then consider American pragmatism, specifically, what the work of George Herbert Mead might offer to thinking about the self as inherently relational and with a capacity for agentic reflexivity, and what Mustafa Emirbayer's use of the work of John Dewey and Arthur Bentley might offer to understandings of relational processes. We also explore the contribution that psychoanalytic thought, especially mid twentieth century British object relations and more recent, more profoundly 'relational', psychoanalytic thinking, might make to understandings of the affective dimensions of relationality. Linking these literatures, we discuss an aspect of Norbert Elias's figurational sociology that addresses the centrality of affective bonds to the constitution of the social. We suggest that these formulations of relationality share a sensibility with recent contributions to the sociology of personal life in their focus on relational processes, and on the particularity and constitutive nature of relationships with significant others, but that they offer a stronger programme for theorizing relationality.i

\section{The sociology of personal life and the 'relational turn'}

The foundations of the sub-field that is now being styled the 'sociology of personal life' (Smart, 2007; May 20I I) were laid by British sociologists studying families in the late 1980s and early 1990s. Janet Finch (1989) and later with Jennifer Mason (Finch and Mason, 1993), approached family relationships through the notion of 'family responsibilities' which were 
seen developing in open-ended processes, not according to pre-existing rules, but rather through explicit and implicit negotiation between individuals within given social and economic contexts. Finch and Mason argued that commitments between, and expectations toward, kin are actively created in particular relationships, although moral frameworks and accumulated commitments constrain negotiation. Soon after this David Morgan (1996) presented his notion of 'family practices', which has been particularly influential in bringing in a process-oriented, relational viewpoint to family sociology. Morgan suggested that 'family' is to be understood as connections, and the quality of these connections, rather than as a specific 'thing': 'the family' (1996: 186). This notion of family practices had a theoretical status, and involved recognition that practices of families could be seen otherwise and are not necessarily tied only to relationships that we understand as family, but might be associated with any relationship that is granted the personal or moral significance traditionally associated with family. ${ }^{i i i} \mathrm{He}$ also suggested that the significance of particular practices does not necessarily mean that they are positively evaluated by those involved, but rather that they are prominent or difficult to ignore from the participants' point of view. ${ }^{\text {iv }}$ In a similar vein Lynn Jamieson's discussion of intimacy (1998) worked with a notion of significant others as those intimates who have a particular significance in, and commitment to, the shaping of a self.

These re-conceptualizations of intimacy and family life opened the way for more radical suggestions about personal life, moving from asserting that relationships matter to expanding the range of relationships that are seen to matter. One of us (Roseneil, 2000; Roseneil and Budgeon, 2004) suggested that in the context of a wider 'queering of the social' in western societies, in which the modern categories of 'homosexual' and 'heterosexual' were being destabilized, the conventional heterosexual family was being decentred in the organization of personal life, as more and more people live outside its boundaries for significant parts of their lives, and friendship, non-conjugal and non-cohabiting intimate relationships become more important (see also Levin, 2004; Holmes, 2004). Liz Spencer and Ray Pahl (2006: 33) noted that one of the major issues in the study of personal relationships is that terms like 'family' and 'friends' do not have shared or stable meanings. They proposed the notion of 'personal community' to encompass all significant relationships in order not to rely on categorical labels that do not recognize the ways in which the boundaries between family and friendship are blurring. 
More recently these directions in research on family and intimate lives have been claimed as part of a newly defined field of inquiry in British sociology. Carol Smart explicates the meaning of the 'personal' as follows:

'The personal' designates an area of life which impacts closely on people and means much to them, but which does not presume that there is an autonomous individual who makes free choices and exercises unfettered agency. This means that the term 'personal life' can invoke the social, indeed it is conceptualized as always already part of the social . . . the field of personal life is the 'me' compared with the 'l' of the individualization thesis (Smart, 2007: 28).

Vanessa May (20II:2) describes the field as being concerned with 'what is sociological about personal life, that is what individual people's personal lives say about society more generally'. The idea was hence not only to understand the experiences of individual persons, but 'also how and why these experiences may in the aggregate follow some general patterns' (201 I: 2). In this delineation, the personal is explicitly defined as relational, which is taken to mean a focus on people whose 'sense of self' is 'constructed in relationships with others, and in relation to others and to social norms' (May 201 I: 5, italics original).

The notion of 'relational' or 'relationality' is now routinely invoked in studies of personal life. In its weak usage, which is the most widespread, 'relational' appears to mean little more than 'concerning (family/ intimate) relationships'. For instance, llene Wolcott and Jody Hughes (1999) discuss the 'relational reasons for divorce' given by people they surveyed, opposing 'relational' reasons to abusive behaviour and external pressures, and Simon Duncan et al (2003) discuss the 'relational commitments' of the mothers in their study. In a rather stronger formulation, others, including Mason (2004), Smart (2007; 20I I), Gabb (20II) and May (20II) engage the notion of the relational as part of a critique of the individualization and transformation of intimacy theses (Beck and Beck-Gernsheim, 1995; 2002; Giddens, 199I, 1992), asserting the continuing significance of family relationships against the social theorists who understand them to be in decline. So, for instance Mason (2004:166) rejects individualization theory in favour of a perspective which sees 'people, selves and values' as 'relational, connected and embedded' in webs of relationships. What this means is that her interviewees' narratives 'were built through relationships they had and connections they made with other people - particularly but not exclusively those whom 
they saw as family and kin' (Mason, 2004:177), and she suggests, therefore, that 'we need to keep the processes of relating in focus, just as much as, if not more than, the individual or the self (2004:167). Jacqui Gabb (20II) explores 'relational living' within families through a feminist Levinasian-inspired ethic of attention to relationships across difference - between humans and animals, parents and children, people and objects. More recent contributions to the project of asserting the importance of embeddedness within relationships, albeit not signing up to the sociology of personal life paradigm, mobilize a notion of 'relational processes' (Jamieson and Milne, 20I2) and defend 'the powerful relational language of "family” (Ribbens McCarthy, 20I2).

Broadly speaking, then, this work understands 'relational' as an orientation that stands in contrast to a focus on 'the individual' (e.g. Smart 2007: 28) and against theories of individualization. In the delineation of personal life as a designated field of sociological research both Smart (2007) and May (20II) state that they are constructing their notion of relationality from the work of George Herbert Mead (1934). ${ }^{\text {vi }}$ Mead is also cited as foundational by Jamieson and Milne (2012). Given this, we begin our excursion into the pragmatist theorization of relationality by looking at Mead's work, which, we believe, offers a more powerful conceptualization of the relational person than has been picked up in the sociology of personal life. In particular it allows us to challenge the idea that the notion of

relationality is necessarily in opposition to a conceptualization of the individuality of the person. In what follows we seek understandings of the emergence of individuality as a relational process.

\section{Relationality in American pragmatism}

Classic American pragmatism, as developed by George Herbert Mead and Charles Cooley, offers a theorisation of relationality through its foundational and influential discussion of the 'social self. Whilst reading Mead as a symbolic interactionist, as many British sociologists do, might imply conceptualizing the ' $\mathrm{l}$ ' and the 'me' as two different sides of the self, a reading of Mead that recognises the pragmatist processual ontology in his work emphasises his argument that the social self consists of the 'me' and the ' $l$ ' as interdependent phases of the self (Kilpinen, 20I3), and that the self is constituted in social relations. In contrast with Smart's (2007) understanding of Mead, which distinguishes between the 'me' as the 'social, interconnected person', with whom the sociology of personal life should be concerned, and 
the 'l' as the 'agentic ego' 'of the individualization thesis' (Smart, 2007:28), we do not think it is helpful, in building a fuller understanding of the relationality of personal life, to prioritize or foreground the 'me'.

In the process oriented thinking of Mead, the 'l' is the phase of the self that enables a person to act beyond habits and social expectations, that enables novelty and creativity (Gronow 2008). The ' $l$ ' is the subject that responds to the present social situation on the basis of past experience, yet that always contains an element of novelty and unpredictability. This 'l', as a creative aspect of the self, and the actions it sets in train, cannot be known thoroughly, in advance or in the present, by others or by the self. The generative 'l' constitutes the distinctiveness of the person, and through the response of the 'l' one gains a critical distance from conventions. According to Mead, the 'me' is the social object of the 'l', a person's selfimage when they look at themselves through the eyes of others, initially those of particular significant others, and later those of 'the generalized other', representing the attitude of the entire social group (Mead, 1934). It is in the 'me' that we become objects to ourselves. The 'l', however, can be reflected by the self only after immediate action as a memory image when in fact the 'l' of the past has already become the 'me' of the present. The unity of the self is closely related to the unity of the 'me' that organizes social attitudes and is associated with the 'conventional and habitual' person (Mead 1934: 174, 197). Without an 'I' no reflection is possible, because there is no observer and actor who could critically view the world and the self. The 'me' alone would be a fully socially determined being. We assume that this is not how sociologists of personal life, such as Smart (2007), wish to understand the person, even as they wish to stress the importance of the social and the 'me' as the subject of the sociology of personal life. To be social requires both aspects - the 'l' and the 'me' - that are different phases of the same process called 'the self' (da Silva 2007; Kilpinen 2008). In turn this social process of the self is a phase of the even larger process of social life. The self does not stand in an ontological opposition to the world, but is a part of it.

In placing social attitudes inside the structure of the self, Mead articulated a pragmatist processual view of reality that considers the emergence and development of the self as an intrinsic aspect of the surrounding world (Da Silva, 2007:7, 55). Hence, 'selves can only exist in definite relationships to other selves. No hard-and-fast line can be drawn between ourselves and the selves of the others, since our own selves exist and enter as such into our 
experience only in so far as the selves of the others exist and enter as such into our experience also' (Mead 196I: 168). Da Silva (2007: 54-55) suggests that Mead is nothing short of revolutionary in his abandonment of the Cartesian notion of self, implying that there is no such thinking entity called the self that stands in opposition to the outside world.

Leaving the 'l' in the equation does not imply individualism, but rather a more complete understanding of the ways in which persons are always parts of larger social processes. The ' $l$ ' is needed for the self to have an ability to reflexively respond to the social phenomena it confronts. Even if the individualization thesis might have overemphasized the ' 1 ' phase of the self, underestimating the 'me' phase, as Smart argues, this does not mean that the opposite would be helpful in developing the sociology of personal life. ${ }^{\text {vii }}$ Rather, we suggest that what is needed is a notion of relationality, drawing on Mead, that would enable us grasp the relational emergence of individuality, of the distinctiveness of each person, as part of the social dynamics of the self. This would enable us to theorize the moments when a person actively intervenes and contributes to the dynamic unfolding and transformation of their relationships, which has been understood in the sociology of personal life in terms of processes of negotiation. With a Meadian understanding we can consider the ways in which the ability to negotiate itself, resting on a capacity for reflexivity, arises from the dynamic interaction between the 'l' and the 'me' within the social self. Action requires reflection, and Mead offers a theory of the agentic reflexivity of the relational person.

More recently, Mustafa Emirbayer (1997) has continued to develop the process-oriented thinking of the classic American pragmatists. Drawing on the work of John Dewey and Arthur Bentley (1949), he proposes a 'manifesto for a relational sociology', in which he identifies as the fundamental dilemma facing sociologists whether to conceive of the social world as consisting primarily of substances or of processes, as static 'things' or as dynamic, unfolding relations. He points out that sociological dualisms, such as 'individual versus society' and 'structure versus agency', propose substances of various kinds. From a substantialist perspective these 'things' constitute the fundamental units not just of reality but also of social inquiry. Conversely, the 'transactional', or relational, viewpoint is interested in the processes, action and interaction in which the participants in these processes emerge. Relational understanding, as advanced by Emirbayer, leaves open the final attribution of the nature of the relation, and also how we should understand those involved. 
There is a clear parallel here with recent sociological thinking about personal lives in which we see a move from 'the family' as a given social or institutional entity to understanding relationships without a final attribution of what they are: this represents the same distinction that Emirbayer considered as the one between substantialism and transactionalism.

Emirbayer further differentiates the relational perspective from substantialism in a way that draws attention to the difference between what we would consider a weaker notion of relationality and more profoundly relational thought. Citing Dewey and Bentley (1949:108), he argues that approaches that are concerned with inter-action between participants who remain intact and unchanged by the interaction are, in fact, a version of substantialism, because they begin with a notion of pre-existing entities 'among' which relations happen (Emirbayer 1997: 285). Participants are seen as bounded and unchanging entities who remain that way throughout the interaction, each independent of the existence of the others. Herein, lies the fundamental difference between interactional substantialism - which we see proposed as 'relational' in much recent sociology of personal life - and the transactional approach that Emirbayer names 'relational sociology'. In contrast, trans-action does not assume a final attribution to the elements or other detachable entities. In the transactional or relational approach, the units involved in transaction derive their meaning, significance and identity from the transaction. The basic unit of analysis then is not the constituent elements of reality, but rather the dynamic, as an unfolding process (Emirbayer 1997; Dewey and Bentley 1949.) For example, one of us (Ketokivi, 2008) suggests that the disruptive event of the loss of a partner by death or divorce can either be seen as a separation of two distinct persons whose ways part (substantialist understanding) or as a process in which not only the relationship, but also persons, undergo a transformation that does not leave them the same.

In the recent literature on personal life there are several ways of conceptualizing relationships as processes that seek to grasp the different dimensions of relationships without an a priori designation of a category of relationship. The concept of relationality as Smart (2007: 48-49), for example, understands it, acknowledges that 'people relate to others who are not necessarily kin by "blood" or marriage, thus allowing considerable flexibility in the approach'. Mason (2004) argues that relationality should not be solely 
understood as a positive good, but should be seen in open-ended terms, noting that sometimes relationality drives people away from draining relationships. Morgan (1996, 20II) likewise argues for conceptual fluidity. All these formulations come close to the pragmatist focus on developing an anti-categorical approach to relationality. However, taking a transactional stance has more far-reaching theoretical implications, as it throws open the central concepts of sociological analysis. Re-conceptualizing the idea of family, for example, from a transactional perspective would mean viewing it as inseparable from the unfolding dynamics of situations and especially from the problematic features of those situations. Any particular family, or 'individual', gains its identity and becomes 'what' it is in relation to surrounding persons, places, meanings and events. Hence, rather than being pre-given bounded entities, they are in a state of becoming within a wider set of relational processes.

\section{Relationality in figurational sociology}

The Meadian line of pragmatist thinking discussed above emphasizes the conscious cognitive and reflexive aspects of relationality, which differ from the psychoanalytic understandings that we address later in the paper, and which are more concerned with the realm of the affective, in both its conscious and unconscious dimensions. We suggest that both the cognitive and the affective are crucial to understanding the ways in which persons emerge and relate to others and the world. In considering the affectivity of relationality we turn first to the work of Norbert Elias (1978) in which he discussed the centrality of affective bonds to the constitution of the social. Elias argued that human interdependencies should be the very heart of sociological inquiry. Like pragmatist thought, Elias's figurational thinking emphasized processes over entities and the particularity of relations and people over an abstract notion of the social. For him, there is no social apart from concrete relations; rather, the social is those relations. Moreover, all relations are understood as part of wider figurations of interdependency. Relations gain their meaning from their position within these wider figurations, which are always dynamic and created by people as a whole - not only by their cognitive capacities but by their whole selves, including their emotional needs and connections. Self for Elias is not an entity but a process: 'A person is in constant movement. He does not only go through a process, but he is a process.' (1978: II8). He developed a notion of 'open people' who are not clearly bounded, but are bound to others through 
affective bonds that become integral parts of the self: 'people look to others for the fulfilment of a whole gamut of emotional needs' (1978: I34).

Drawing on the language of chemistry, Elias used the notion of valency to refer to the primary way in which people are directed towards others via deeply affective and personal bonding. He pictured a person as having many valencies at any given time. All of these are directed toward other people: some are already firmly connected with certain people, while others are free and open, and search for people with whom to form bonds. And, as Somers (1994: 622) suggests, this idea of valency means that we might also think about how relationships can be 'more or less bonded'. Elias (1978: 135-6) offered the example of losing a loved one as a simple example of the durability typical of these elementary emotional bonds. When a beloved person dies, it is not an event in the social world outside the survivor. Rather, the emotional bond is to be understood more radically: losing a beloved means the survivor has lost a part of herself or himself. This can be understood via the valency that has been attached and fixed to that person. When the person dies the valency is torn out and an integral part of the self and 'I-we' images have been broken off. As a person's valencies and bonds are particular, and differ from every other person's bonds, to understand a whole range of interdependencies we need the l-perspective - that is, how a person feels about their unique figuration of relations.

Elias stressed, therefore, the importance of personal interdependencies and emotional bonds as that which knits society together, and indeed, as that which constitutes the social. He was, then, among the first sociologists to emphasize the personal as a person's particular valencies and web of relationships, as distinct (although always fundamentally connected to) the social as something general or universal beyond particular people. From a figurational perspective, then, we would suggest that instead of asking, as May (20I I: 2) does 'what individual people's personal lives say about society more generally', it might be more fruitful to re-phrase the question so as to ask how people's lives and relations are intertwined through wider chains of interdependencies, which are not informative about society but themselves are society in that setting. 


\section{Relationality in psychoanalytic thought}

To anyone schooled in psychoanalysis, there are elements of Elias' relational thinking that sound familiar. His ideas have clear resonances with the British object relations tradition within psychoanalysis that had been developing during the period that Elias was writing indeed Elias emphasised the fundamental dependence of the human infant and the importance of the developmental process. viii We suggest that drawing on some aspects of psychoanalytic thinking might be productive in efforts to deepen understandings of personal life as relational.

Whilst the origins of a psychoanalytic conceptualisation of relationality stretch back to Freud's theory of identification, ${ }^{\text {ix }}$ a distinctive school of 'relational psychoanalysis' developed from the early 1980s in the United States in the work of Jay R. Greenberg and Stephen A. Mitchell (1983), who posited a relational model in opposition to classical Freudian drive theory. This 'new tradition' (see Mitchell and Aron, 1999; Aron and Harris, 2005), which now occupies an influential position in psychoanalysis internationally, draws on three longstanding bodies of thinking in psychoanalysis: the American interpersonal tradition (Stack Sullivan, 1953; Fromm, 194I; 1947), which emphasised the importance of understanding the network of relationships within which individuals exist; the British object relations tradition (Klein, 1948; Fairbairn, 1952; Winnicott, 1958, 1965; Bowlby, 1969); and the more recent work of American psychoanalytic feminists (Dinnerstein, 1976; Chodorow, 1978; Benjamin, 1988, 1995, 1998; Dimen, 2003; Layton, 2004). Each of these lineages of theory and practice posed its own challenges to the monadic model of drive theory, with its primary focus on intrapsychic processes, on the quest for rational control by the ego, and the developmental goal of separation and autonomy. Their shared orientation is to conceptualize the self as fundamentally relationally constituted.

Relational psychoanalysis understands the dependent infant as becoming aware of the boundaries of her self, and coming to into being as a separate person, through her relationship with the mother/ primary-carer. The matrix of mother/primary-carer-child provides the very conditions of possibility of existence for the young, dependent child. As Winnicott (1965:39) famously said, 'there is no such thing as a baby (apart from maternal provision).' It is the internalization of the benign presence of the mother/ primary carer that facilitates the emergence of the child's individuality and her 'capacity to be alone'. Hence, 
from the beginning, the self is intrinsically social, our sense of autonomy and agency inherently relational. Our subjectivities and personal worlds are shaped, over time, throughout our lives, 'by the presence and actions of the other' (Bollas, 1993:56), as the traces of encounters and relationships are sedimented within us, producing 'the feeling of being inhabited by our history and its objects' (Bollas, 1993:6I). In Kleinian terms, through processes of identification and introjection, we 'take in' aspects of significant others, and through projection and projective identification ${ }^{\times}$we expel unwanted feelings and that which we refuse to recognize in ourselves, so that we experience such feelings as belonging to the other (Laplanche and Pontalis, 1973), particularly those with whom we are in intimate relation. As early as the 1950s, Joan Riviere articulated a profoundly relational psychoanalysis as follows:

'There is no such thing as a single human being, pure and simple, unmixed with other human beings. Each personality is a world in himself, a company of many. That self, that life of one's own, which is in fact so precious though so casually taken for granted, is a composite structure which has been and is being formed and built up since the day of our birth out of countless never-ending influences and exchanges between ourselves and others [...] These other persons are in fact therefore parts of ourselves, not indeed the whole of them but such parts or aspects of them as we had our relation with, and as have thus become parts of us. And we ourselves similarly have and have had effects and influences, intended or not, on all others who have an emotional relation to us, have loved or hated us. We are members one of another' (Riviere, 1952: 166-167).

Building on these long-established ideas in psychoanalysis, but moving beyond the classical focus on object relations, contemporary relational psychoanalysis has made attending to subject-subject relations one of its distinctive projects. The notion of intersubjectivity - 'the field of intersection between two subjectivities, the interplay between two different subjective worlds' (Benjamin, 1995:29) - emphasizes the permeability of the boundaries of the self, and the ways in which 'the apparently isolated subject constantly assimilates what is outside itself' (Benjamin, 1998:79). Jessica Benjamin $(1988,1995,1998)$ argues that the self is, in an ongoing way, reciprocally constituted in relation to the other, and therefore depends on the other's recognition. Importantly, she draws attention (1988) to the psychically challenging aspects of relationality - to the fear that inheres in the dependency that 
compromises the autonomy of the self, and to the repudiation of dependency that is a widespread feature of psychic, social and political life. She points to the difficulties that people have in recognizing the other as an equivalent centre of experience, and to the tensions between sameness and difference that exist within all relationships. 'An intersubjective theory of self, she suggests 'is one that poses the question of how and whether the self can actually achieve a relationship to an outside other without, through identification, assimilating or being assimilated by it' (Benjamin, 1998:80). Relating to the other as an object is part of psychic life - the intrapsychic dimension of experience - but relating to the other as a subject, is the intersubjective dimension, and both need to be theorized in order 'to account both for the pervasive effects of human relationships on psychic development and for the equally ubiquitous effects of internal psychic mechanisms and fantasies in shaping psychological life and interaction' (Benjamin, 1995:30).

Stephen Mitchell (2000: 57) further specifies the psychosocial orientation of relational psychoanalysis, proffering an understanding of the self as constituted out of a pre-existing 'relational, social, linguistic matrix'. From this matrix are forged 'individual psyches with subjectively experienced interior spaces':

Those subjective spaces begin as microcosms of the relational field, in which macrocosmic interpersonal relationships are internalized and transformed into a distinctly personal experience; and those personal experiences are, in turn, regulated and transformed, generating newly emergent properties, which in turn create new interpersonal forms that alter macrocosmic patterns of interaction. Interpersonal relational processes generate intrapsychic relational processes which reshape interpersonal processes reshaping intrapsychic processes, and so on in an endless Mobius strip in which internal and external are perpetually regenerating and transforming themselves and each other (Mitchell, 2000: 57).

This emphasis on the affective, intersubjective relational emergence of the self might be seen as complementing Mead's (1934) more cognitive articulation of the agentic reflexive self as emerging through taking the perspective of particular others and gaining a capacity to view the self in light of relations with others, and is perhaps less challenging to sociological ways of thinking than is the work of the feminist psychoanalyst Bracha Ettinger (2006a, 2006b). At the heart of Ettinger's theory is the concept of trans-subjectivity, which she understands as 
originating in the 'language-defying state' prior to birth, in the 'transgressive encounter between I and non-I grounded in the maternal womb/ intra-uterine complex' (Ettinger, 2006b: 2 I8). Every person, by virtue of having once been a foetus, has experienced, she argues, a state of jointness in separation, of being neither one nor two. This gives rise to 'the matrixial stratum of subjectivization', the 'feeling knowing' that Ettinger calls 'a dynamic borderspace', that constitutes both differentiation and linking, connectivity and coinhabitation. This 'matrixial borderspace' is a trans-subjective and sub-subjective psychic space that precedes and sometime over-rides the separate subject. It is what accounts for the experience of 'strangeness in me', and of porosity and the breaching of boundaries between intimate others. Ettinger's more profound, earlier conceptualization of the relational person and relational processes offers us a radical understanding of subjectivity- asencounter, and her rather difficult language provokes us to think about trans-subjective unconscious transmission, the affect that flows so powerfully between people in intimate relation, transgressing the boundaries of the individual. Her work might also provide a way of thinking about the capacity for what she calls 'shareability', or, more prosaically, a sense of belonging to others, to an intimate group or a larger community. It suggests that the potential to connect, relate, bond and communicate beyond the boundaries of the embodied individual rests on our earliest experiences of simultaneous jointness and separation. Whilst employing a radically different language from the sociology of personal life, this attempt to move beyond the binaries of individual and society is not perhaps so alien.

\section{Concluding Discussion}

With a focus on their particular conceptualisations of relationality, we have here ranged across a number of literatures that are rarely, if ever, brought into dialogue, but which, we think, might have something to offer to the conceptual sharpening of the sociology of personal life. To link our earlier discussion of Mead with the psychoanalytic literature, each proposes a different vocabulary for thinking about the emergence of the self as relational, albeit the focus in latter is not on 'the generalized other' that for Mead represents the social group as a whole, but on relationships with particular significant others. The Meadian 'l' is present in relational psychoanalytic thought as the aspect of the self that protects it from assimilating with the other, and the 'me' as the aspect of the self that seeks connection and recognition. Somewhat similar relational dialectics characterize both bodies of literature. 
Drawing on psychoanalytic literature does not necessarily mean understanding a person in terms of their psychic life alone. Rather it allows us to deepen our understanding of the emotional importance of struggles to protect the self from assimilating with a significant other, which are so much part and parcel of the lived experience of personal life, and which are, perhaps, particularly intense in the contemporary social formation, when autonomy and self-responsibility are valorised and interdependence and vulnerability repudiated (Roseneil, 2007; Ketokivi, 2008). As Cooley (1967), another classic pragmatist and Mead's contemporary, has pointed out, we interpret the need for even the most forceful outburst of self-feeling, such as crying 'me' or 'mine', as drawing its very meaning not from what is already distinct, but from what is shared with others. Yet, at the moment of analysis there are certain however short-lived stabilizations of the person, that in the flow of relational dynamics represent the 'l' and the 'me' aspects of the self.

Just as we might note the parallels in the theorisation of relationality in relational psychoanalysis and in the work of the American pragmatists, we also observe that Elias's (1978:135) formulations of the emotional valencies through which others become parts of ourselves are remarkably close to Riviere's (1952) writings about how we become 'members' of one another. Likewise Cooley (1967: 824) suggested that loving others intensively or for a long time tends to obliterate our sense of divergent individuality and to assert these others as part of the self.

So we see a significant affinity between the various relational viewpoints presented in this article, and we propose that a wider knowledge of, and engagement with, theorizations of the relational person and relational processes might strengthen understandings of personal life. ${ }^{\mathrm{xi}}$ We are aware of how uncomfortable some sociologists become when psychoanalytic interpretations are made of social phenomena, but we suggest that like any other theoretical understanding, the claims of psychoanalytic thinking do not need to have an a priori status in social inquiry; rather they can be seen as theoretical resources that help make sense of certain empirical observations (see also Lawler 2008).

For us, seeking to work with relational psychoanalytic thinking in understanding personal lives has meant attending, in empirical research on contemporary personal life, to the relational constitution of the person through her particular history of object relations - the 
processes by which primary carers and significant others have been internalized - across biographical time, and in a lateral matrix of relationships (Roseneil, 2009). . $^{\text {ii }}$ This means recognizing that people subjectively experience (to varying degrees and in differing ways) 'interior' psychic space and individuality as central to the personal and at the same time such experiences are always psychosocial - that they are relationally mediated, shifting in the context of the dynamics of relationships. The intrapsychic and the interpersonal, the psychic and the social, are fundamentally entangled in personal relationships and even the intrapsychic has relational rather than individual origins. Furthermore, taking these profound conceptualizations of relationality seriously has meant seeking to grasp that however bounded and separate the individual embodied human being might appear to be, particularly in de-traditionalized, late modern societal contexts that demand the enactment of individuality and an ethos of individualism, as suggested by the theorists of individualization, $s /$ he is a fragile, permeable achievement, a vulnerable being-in-process, whose individual selfhood is always open to the possibility of, in Judith Butler's terms, 'being undone' (1997; see also Ketokivi, 2008).

In suggesting that sociologists who are attracted to the notion of relationality might fruitfully take some theoretical excursions across the terrain we have mapped here we are not claiming that a rethinking of ontologies of relationality is in itself enough. We consider this work to offer vital resources in opening up and renewing our thinking about ontologies of the social - but we also firmly believe that it is our task as sociologists to find ways of bringing these ideas into the framing, conceptualization and analysis of the lived realities, experiences and forms of social organisation with which our empirical research on personal life grapples.

\footnotetext{
${ }^{\mathrm{i}}$ There are extensive debates in anthropology about the concepts of relationality, personhood, the self and the in/dividual, particularly as they intersect with understandings of kinship, that are outside our purview in this article (see, for example, Smith, 2012; Strathern, 20I4). Like Smith (20I2) we do not offer a definitive differentiation between the concepts of "person" and "self", but rather our working distinction here is to use the notion of "person" as the more overarching concept that captures the fully social, interconnected, bonded human being in her entirety, and given that the 'sociology of personal life' stakes a claim to a wider remit than might a 'sociology of the self'.

ii The notion of relationality is widely used in European sociology under the influence of Bourdieu (1984) and Bourdieu and Wacquant (1992), and by those concerned with social
} 
networks and globalization, with Crossley $(20 \mathrm{II})$ and Donati $(20 \mathrm{II})$ claiming the territory of 'relational sociology', and in the United States under the influence of White and Tilly (see Mische, 20II) and the pragmatist tradition discussed later.

iii An earlier parallel move had been implicitly made by US anthropologist Weston (1991) who explored the practices and meanings by which lesbians and gay men were creating 'families of choice'. Carsten (2004) outlines a longer term transformation within anthropology from the study of kinship structures to a concern with 'relatedness' which Smart (2007) sees as similar to that which has led to the new paradigm of personal life in sociology. We would also emphasise the foundational contribution of Strathern (1992). iv See Morgan (20l la; b) for his later elaborations and reflections on the notion of family practices.

"In a broadside against the move to establish a 'sociology of personal life', Ribbens McCarthy (20I2), Edwards et al (20I2) and Edwards and Gillies (20I2a; b) argue for the preservation of the concept of 'family'. Paradoxically, given our argument here, one of their main criticisms is that the notion of 'personal life' is too centred on the (relational) individual, whereas 'family' enables, indeed, requires, a stronger engagement with the relationality of 'close-knit selves' (Ribbens McCarthy, 20I2).

vi Smart (20I I) also references a lineage of feminist philosophy that has conceptualised the self as relational (e.g. Griffiths, 1995; Meyers, 1997).

vii Elsewhere (Roseneil, 2006, 2007, 2009) offers a rather different critical engagement with the individualization thesis from a psychosocial perspective.

viii Elias collaborated with the psychoanalyst Foulkes in establishing the practice of group analysis in the late 1940s (Brown, 1997; Lavie, 2005), and in his final work (Elias, 2014) he made explicit his life-long sympathetically critical engagement with Freud and psychoanalysis (Mennell, 20I I).

ix Freud's emphasis on identification grew stronger over time, and in his later work he argued that the ego is constructed on the basis of identifications, as 'a precipitate of abandoned object cathexes and [...] contain[ing] the history of these object choices' (Freud, 1984 [1923]: 368).

× Projective identification is the 'putting of a part of oneself into another person with whom one then identifies' (Mitchell, 1986:58).

${ }^{x i}$ For examples of how relational thinking about personal life might be worked with methodologically, see Roseneil (2009) and Castrén and Ketokivi, (forthcoming).

\section{References}

Aron L, Harris A (2005) Relational Psychoanalysis Volume 2: Innovation and Expansion. Hillsdale, N.J: The Analytic Press.

Beck U, Beck-Gernsheim E (1995) The Normal Chaos of Love. Cambridge and Malden: Polity Press.

Beck U, Beck-Gernsheim E (2002) Individualization. London and Thousand Oaks: Sage.

Benjamin J (1988) The Bonds of Love: Psychoanalysis, Feminism and the Problem of Domination. New York: Pantheon.

Benjamin J (1995) Like Subjects, Love Objects: Essays on Recognition and Sexual Difference. New Haven: Yale University Press.

Benjamin J (1998) Shadow of the Other: Intersubjectivity and Gender in Psychoanalysis. London and New York: Routledge. 
Bollas C (1993) Being a Character: Psychoanalysis and Self Experience. London and New York: Routledge.

Bourdieu P (1984) Distinction: A Social Critique of the Judgement of Taste. London: Routledge and Kegan Paul.

Bourdieu P, Wacquant LJD (1992) An Invitation to Reflexive Sociology. Chicago: University of Chicago Press.

Bowlby I (1969) Attachment and Loss. Volume I: Attachment. London: Basic Books.

Brown, D (1997) Conversation with Norbert Elias. Group Analysis 30: 5I 5-524.

Butler J (1997) The Psychic Life of Power. Theories of Subjection. Stanford: Stanford University Press.

Carsten J (2004) After Kinship. Cambridge and New York: Cambridge University Press.

Castrén, A-M and Ketokivi, $\mathrm{K}$ (forthcoming) Studying the complex dynamics of family relationships: a figurational approach. Sociological Research Online.

Chodorow N (1999) Toward a relational individualism. In: Mitchell SA, Aron L (eds) Relational Psychoanalysis: The Emergence of a Tradition. Hillsdale, N.J, The Analytic Press.

Cooley C (1967 [1909]) The social self. In: Parsons T, Shils E, and Naegele K (eds) Theories of Society. Foundations of Modern Sociological Theory. Vol. 2. New York: The Free Press of Glencoe, 822-8.

Crossley N (20I I) Towards Relational Sociology. London and New York: Routledge.

Da Silva FC (2007) G. H. Mead. A Critical Introduction. Cambridge and Malden: Polity Press.

Dewey J, Bentley AF (1949) Knowing and the Known. Boston: Beacon Press.

Dimen M (2003) Sexuality, Intimacy, Power - Relational Perspectives. London and New York: Routledge.

Dinnerstein D (1976) The Mermaid and the Minotaur: Sexual Arrangements and Human Malaise. New York: Harper \& Row.

Donati P (20II) Modernization and relational reflexivity. International Review of Sociology 2I(I): $21-39$.

Duncan S, Edwards R, Alldred P, and Reynolds T (2003) Mothers and childcare: policies, values and theories. Children and Society 18(4): 245-65.

Edwards R, Gillies V (20I2) Farewell to family? Notes on an argument for retaining the concept. Families, Relationships and Societies I(I): 63-9.

Edwards R, Ribbens McCarthy J, and Gillies V (2012) The politics of concepts: family and its (putative) replacements. British Journal of Sociology 63(4): 730-46.

Elias N (1978) What is Sociology? New York: Columbia University Press.

Elias N (200I) The Society of Individuals. New York: Continuum.

Elias N (2014) Freud's concept of society and beyond it. In: Joly M (ed.) Supplements and Index to the Collected Works, Collected Works vol. I8. Dublin: University College Dublin Press, 13-52.

Elias N, Kilminster R (199I) The Symbol Theory. London: Sage.

Emirbayer M (1997) Manifesto for a relational sociology. American Journal of Sociology 103(2): $28 \mathrm{I}-317$.

Ettinger B (2006a) The Matrixial Borderspace. Minneapolis: University of Minnesota Press.

Ettinger B (2006b) Matrixial trans-subjectivity. Theory, Culture and Society 23(2-3): 218-22.

Fairbairn WRD (1952) Psychoanalytic Studies of the Personality. London: Tavistock

Publications.

Finch J (1989) Family Obligations and Social Change. Cambridge: Polity. 
Finch J, Mason J (1993) Negotiating Family Responsibilities. London: Tavistock/Routledge. Fromm E (194I) Escape from Freedom. New York: Holt, Rinehart and Winston.

Fromm E (1947) Man for Himself. An Inquiry into the Psychology of Ethics. Greenwich, Conn.: Fawcett Premier.

Freud S (1984 [1923]) The Ego and the Id. In: Freud S On Metapsychology: The Theory of Psychoanalysis. Harmondsworth: Penguin.

Gabb J (20II) Family lives and relational living: taking account of otherness. Sociological Research Online 16(4).

Giddens A (1991) Modernity and Self-Identity: Self and Society in the Late Modern Age. Cambridge and Malden: Polity Press.

Giddens A (1992) The Transformation of Intimacy: Sexuality, Love and Eroticism in Modern Societies. Cambridge and Malden: Polity Press.

Greenberg J, Mitchell S (1983) Object Relations in Psychoanalytic Theory. Cambridge, MA.: Harvard University Press.

Griffiths M (1995) Feminisms and the Self: The Web of Identity. London and New York: Routledge.

Gronow A (2008) The over- or the undersocialized conception of man? Practice theory and the problem of intersubjectivity. Sociology 42(2): 243-59.

Hollway W (20II) Rereading Winnicott's 'primary maternal preoccupation'. Feminism and Psychology 22(I): 20-40.

Holmes M (2004) An equal distance? Individualisation, gender and intimacy in distance relationships. The Sociological Review 52(2): 180-200.

Jamieson L (1998) Intimacy: Personal Relationships in Modern Societies. Cambridge and Malden: Polity Press.

Jamieson L, Milne S (2012) Children and young people's relationships, relational processes and social change: reading across worlds. Children's Geographies 10(3): 265-78.

Ketokivi, K (2008) Biographical Disruption, the Wounded Self and the Reconfiguration of Significant Others. In Widmer E, Jallinoja R (eds) Beyond the Nuclear Family: Families in a Configurational Perspective. Bern: Peter Lang, 255-278.

Kilpinen E (20I3) George H. Mead as an empirically responsible philosopher: the 'philosophy of the act' reconsidered. In: Burke T, Skowronski K (eds) George Herbert Mead in the Twenty-First Century. Lanham, MD: Lexington Books, 3-20.

Klein M (1948) Contributions to Psycho-analysis 1921-1945. London: The Hogarth Press. Laplanche J, Pontalis J-B (1973) The Language of Psycho-analysis. London: Hogarth Press. Lavie J (2005) The lost roots of group analysis: taking interrelational individuals seriously. Group Analysis 35(2): 333-5.

Lawler S (2008) Identity. Sociological perspectives. Cambridge: Polity Press.

Layton L (2004) Who's That girl? Who's That Boy? Clinical Practice Meets Postmodern Gender Theory. New York: Analytic Press.

Levin I (2004) Living apart together: a new family form. Current Sociology 52(2): 223-40.

Mason J (2004) Personal narratives, relational selves: residential histories in the living and telling. The Sociological Review 52(2): 162-79.

Mason J (2006) Mixing methods in a qualitative driven way. Qualitatitve Research 6(I): 9-25. 
May V (ed.) (20I I) Sociology of Personal Life. Basingstoke: Palgrave Macmillan.

Mead GH (1934) Mind, Self, and Society from a Standpoint of a Social Behaviorist. Chicago and London: University of Chicago Press.

Mead GH (196I) Internalized others and the self. In: Parsons T, Shils E, and Naegele K (eds) Theories of Society. Foundations of Modern Sociological Theory. Vol. 2. New York: The Free Press of Glencoe, 829-30.

Mennell S (20II) Sociology Needs a Historical Social Psychology: Norbert Elias's Final

Critique of Sigmund Freud. Paper given at the British Sociological Association Sociology, Psychoanalysis and the Psychosocial Study Group Inaugural Meetings, Birkbeck, University of London October 201 I. Available at:

http://www.stephenmennell.eu/docs/pdf/SJMEliasFreud.pdf.

Meyers DT (ed.) (1997) Feminists Rethink the Self. Boulder: Westview Press.

Mische A (20 I I) Relational sociology, culture and agency. In: Scott J, Carrington P (eds) Sage Handbook of Social Network Analysis. London and Thousand Oaks: Sage.

Mitchell SA, Aron L (eds) (1999) Relational Psychoanalysis: The Emergence of a Tradition. Hillsdale, N.J, The Analytic Press.

Mitchell SA (2000) Relationality: From Attachment to Intersubjectivity. Hillsdale, NJ: The Analytic Press.

Morgan D (1996) Family Connections: An Introduction to Family Studies. Cambridge: Polity.

Morgan DHG (20I la) Rethinking Family Practices. Basingstoke and New York: Palgrave Macmillan.

Morgan DHG (20 I Ib) Locating 'family practices'. Sociological Research Online I6(4).

Pollock G (2008) Mother trouble. Studies in the Maternal I (I). Available at: www.mamsie.bbk.ac.uk/back_issues/issue_one/GriseldaPollock.pdf

Ribbens McCarthy J (20I2) The powerful relational language of 'family': togetherness, belonging and personhood. The Sociological Review 60(I): 68-90.

Riviere J (1952) The unconscious phantasy of an inner world reflected in examples from literature. International Journal of Psycho-Analysis 33: 160-72.

Roseneil, S (2000) Queer Frameworks and Queer Tendencies: Towards an Understanding of Postmodern Transformations of Sexuality', Sociological Research Online, Vol. 5, No. 3, 2000:I-19. http://www.socresonline.org.uk/5/3/roseneil.html

Roseneil, S, Budgeon, S (2004) 'Cultures of Intimacy and Care Beyond the Family: Personal Life and Social Change in the Early Twenty-First Century”, Current Sociology 52(2), 2004:135-I59.

Roseneil, S (2006) The Ambivalences of Angel's “Arrangement”: a psycho-social lens on the contemporary condition of personal life, The Sociological Review, 54 (4), 846-868.

Roseneil, S (2007) Queer Individualization: the transformation of personal life in the early $21^{\text {st }}$ century, NORA: Nordic Journal of Feminist and Gender Research, I5 (2/ 3), 84-99.

Roseneil, S (2009) Haunting in an age of individualization: subjectivity, relationality and the traces of the lives of others, European Societies I I (3), 4 I I-430

Smart C (2007) Personal Life. Cambridge: Polity Press.

Smart C (20II) Relationality and socio-cultural theories of family life. In: lallinoja R, Widmer E (eds) Families and Kinship in Contemporary Europe. Basingstoke: Palgrave Macmillan, 13-28.

Smith K (2012) From dividual and individual selves to porous subjects. The Australian Journal of Anthropology 23(I): 50-64. 
Somers M (1994) The narrative constitution of identity: a relational and network approach. Theory and Society 23(5): 605-49.

Spencer L, Pahl R (2006) Rethinking Friendship: Hidden Solidarities Today. Princeton, NJ: Princeton University Press.

Strathern, M (1992) After Nature: English Kinship in the Late Twentieth Century. Cambridge: Cambridge University Press.

Sullivan HS (1953) The Interpersonal Theory of Psychiatry. New York: The William Alanson White Psychiatric Foundation.

Weston K (199I) Families We Choose: Lesbians, Gays and Kinship. New York: Columbia University Press.

White H (1992) Identity and Control. Princeton, N.J: Princeton University Press.

Winnicott DW (1958) Collected Papers. Through Paediatrics to Psychoanalysis. London: Tavistock Publications.

Winnicott DW (1965) The Family and Individual Development. London: Tavistock Publications. Wolcott I, Hughes J (1999) Towards Understanding the Reasons for Divorce, Working Paper No. 20. Melbourne: Australian Institute of Family Studies.

\section{Acknowledgements}

This article began life in discussions at a workshop, "Tracing the 'Tricky Middle Ground' of Relationality" at the Institute for Public Knowledge, New York University in 20 I I, and continued within the "Belonging Today" Working Group at IPK. We thank the directors, Craig Calhoun and Eric Klinenberg, for their generous support, and all the participants of the Working Group.

\section{Biographies}

Sasha Roseneil is Professor of Sociology and Social Theory and Director of the Birkbeck Institute for Social Research at Birkbeck, University of London. She is Professor II in Sociology in the Centre for Gender Research, University of Oslo, and she is a practising group analyst and psychoanalytic psychotherapist. Her recent books include Social Research after the Cultural Turn (2012, Palgrave, ed. with Stephen Frosh), Remaking Citizenship: gender, women's movements and diversity (2012, Palgrave, ed. with Beatrice Halsaa and Sevil Sümer), and Beyond Citizenship? Feminism and the transformation of belonging (2013, Palgrave).

Kaisa Ketokivi works as a Research Fellow and Lecturer at the Department of Social Research, University of Helsinki and as a Fellow at the Institute for Public Knowledge, New York University. She is a founding member of "Belonging Today" Working Group at NYU. She is the author of "The intimate couple, family and the relational organization of close 
relationships" (Sociology, 2012). Her earlier and forthcoming work on relationality, disruptive life events, families and other personal relationships appears in European Societies, Families, Relationships, Societies, and Contemporary Social Science. See her full publication record at http://blogs.helsinki.fi/kkuurne/in-english/ 